Journal of Animal and Veterinary Advances 9 (22): 2811-2817, 2010

ISSN: $1680-5593$

(C) Medwell Journals, 2010

\title{
Water Thermocline Confirms Susceptibility of Tilapia Cultured in Lakes to Streptococcus agalactiae
}

\author{
${ }^{1}$ M.N.A Amal, ${ }^{1}$ M. Zamri-Saad, ${ }^{2}$ A.R. Zulkafli , ${ }^{3}$ A. Siti-Zahrah, \\ ${ }^{3} \mathrm{~S}$. Misri, ${ }^{3} \mathrm{~B}$. Ramley, ${ }^{3} \mathrm{H}$. Shahidan and ${ }^{1} \mathrm{M}$. Y. Sabri \\ ${ }^{1}$ Department of Veterinary Pathology and Microbiology, Faculty of Veterinary Medicine, \\ University Putra Malaysia, Serdang 43400, Selangor, Malaysia \\ ${ }^{2}$ Freshwater Fisheries Research Center, Jelebu 71650, Negeri Sembilan, Malaysia \\ ${ }^{3}$ National Fish Health Research Centre (NaFisH), Fisheries Research Institute (FRI), \\ Batu Maung 11960, Penang, Malaysia
}

\begin{abstract}
A study was conducted on water quality profiling to confirm susceptibility of tilapia cultured in lakes to Streptococcus agalactiae infection. A total of 1,010 and 719 tilapias of different sizes were collected from two lakes; the Kenyir and Pedu lakes, respectively. They were randomly sampled for a period of 24 months. Swabs of brain, eye and kidney were streaked directly onto blood agar before $S$. agalactiae was identified by the API 20 STREP kit, Slidex Strepto-kit and PCR technique. The water temperature (thermocline) and dissolved oxygen profiling were determined at $1 \mathrm{~m}$ intervals for up to $20 \mathrm{~m}$ deep. Water clarity and flow rate were also recorded using Secchi disk and a current meter. S. agalactiae was successfully isolated from both lakes throughout the year, ranging between 2 and $78 \%$. Isolation was more frequent during the hot and dry months of both years. During this period, the mean water temperature was $>29^{\circ} \mathrm{C}$ for up to $8 \mathrm{~m}$ deep due to the significantly $(p<0.05)$ clearer water and slow rate of water flow that allowed deeper light penetration and enhanced heat retention. Water thermocline that showed a drop in water temperature was observed only in Kenyir lake at $>12 \mathrm{~m}$ deep. This and the slow water flow kept the water temperature at $4 \mathrm{~m}$ deep where tilapias under the cage culture system were kept to remain high causing stress to tilapia and increases susceptibility to $S$. agalactiae. Dissolved oxygen profiling, however remained high at $>5 \mathrm{mg} \mathrm{L}^{-1}$ for up to $8 \mathrm{~m}$ deep and did not give adverse effects to susceptibility of tilapia to $S$. agalactiae.
\end{abstract}

Key words: Water profiling, lakes, tilapia, Streptococcus agalactiae, temperature, Secchi disk

\section{INTRODUCTION}

Streptococcal disease in tilapias have become a major problem in tilapias farming and contributed to severe economic losses (Shoemaker and Klesius 1997; Suanyuk et al., 2008; Mian et al., 2009; Najiah et al., 2009). The emerging fish pathogen, group B Streptococcus agalactiae has been shown to cause significant morbidity and mortality among a variety of freshwater and saltwater fish species throughout the world (Robinson and Meyer, 1966; Plumb et al., 1974; Evans et al., 2002). According to Evans et al. (2006), Streptococcus agalactiae had been noted as one of the major bacteria species that effect tilapias production in the world.

The simple presence of Streptococcus in the environment of the fish is inadequate to cause a disease outbreak. Other factors usually come into play such that either the pathogen has an advantage over the host or the immune system of the host is compromised in some way, increasing its susceptibility to the pathogen (Yanong and Francis-Floyd, 2002). Water quality had been noted as the most important element in aquaculture industry and deterioration in water quality can contribute to the disease development due to stressed aquatic organism. From the previous study, some stressors that have been associated with Streptococcal outbreaks include high water temperature, slow rate of water flow and the size of fish (Amal et al., 2010). Moreover, stressful culture conditions and high stocking densities also increase the susceptibility of fishes to Streptococcal infection (Chang and Plumb, 1996; Bunch and Bajerano, 1997; Bowser et al., 1998; Shoemaker et al., 2000; Yanong and Francis-Floyd, 2002; Mian et al., 2009).

This study was conducted to investigate the significance of water profiling, particularly water temperature, dissolved oxygen, clarity and water flow rate

Corresponding Author: M. Zamri Saad, Department of Veterinary Pathology and Microbiology, Faculty of Veterinary Medicine, University of Putra Malaysia, Serdang 43400, Malaysia 
on the prevalence of Streptococcus agalactiae infection to tilapia kept in floating net-cages culture in reservoirs.

\section{MATERIALS AND METHODS}

Sampling site: The present study was carried out at floating net cage cultures in Kenyir lake, Terengganu and Pedu lake, Kedah, Malaysia. The main function of Kenyir lake was to produce electricity (hydroelectric) while Pedu lake was mainly used for the irrigation of paddy field. Both sampling sites had $>200$ wooden and steel floating cages measuring about $6 \mathrm{~m}$ in length $\mathrm{x} 5 \mathrm{~m}$ in width $\mathrm{x} 4 \mathrm{~m}$ deep. The mean depth of water at sampling sites in Kenyir lake and Pedu lake were $69.2 \pm 7.4 \mathrm{~m}$ and $20.5 \pm 3.0 \mathrm{~m}$, respectively. Stocking densities of tilapias ranged between 1000 and 3000 fishes per cage depending on fish size. The fish were fed commercial fish pellet twice per day.

Fish sampling: A total of $1,010(207.89 \pm 138.71 \mathrm{~g})$ and 719 $(232.92 \pm 107.26 \mathrm{~g})$ tilapia of different sizes were randomly sampled from Kenyir lake and Pedu lake, respectively. The samplings were carried out at monthly intervals for a period of 24 months, starting from January 2007 to December 2008.

Bacterial isolation and identification: Swab samples, taken from brain, eye and kidney were streaked directly onto tryptic soy agar (Merck, Germany) added with 5\% human blood and incubated for $18-24 \mathrm{~h}$ at $37^{\circ} \mathrm{C}$. The dominantly grown bacteria were sub-cultured to get a pure colony.

All of pure isolates were subjected to gram stain, catalase and oxidase tests. The biological and serological type of all gram positive and catalase-negative isolates were determined by API 20 STREP and Slidex Strepto-kit (bioMerieux, France) (Suanyuk et al., 2008). Classification of bacterial genus and species was determined using Bergey's Manual of Systemic Bacteriology (Holt et al., 1994) and the APILAB PLUS program (bioMérieux, France).

Streptococcus agalactiae was also identified using the PCR method. Total cellular DNA of Streptococcus agalactiae identified earlier by API 20 STREP and Slidex Strepto-kit (bioMérieux, France) was extracted with Wizard Genomic DNA Purification Kit (Promega, USA) according to the manufacturer's protocol. The extracted DNA was then further evaluated by PCR for $S$. agalactiae specific section of $16 \mathrm{~S}$ rRNA region with forward primers 5' [GCT ATA CAT GCA GTA GAA CGC TGA] 3' and reverse primer 5' [ACG ACT TCA CCC CAA TCA TCT AT] 3' and cycling conditions described as follows; 1 cycle at $94^{\circ} \mathrm{C}$ for $2 \mathrm{~min}$ for initial denaturation followed by 34 cycles at $94^{\circ} \mathrm{C}$ for $1 \mathrm{~min}$ for denaturation step, $42^{\circ} \mathrm{C}$ for $1 \mathrm{~min}$ for annealing step, $72^{\circ} \mathrm{C}$ for $2 \mathrm{~min}$ for extension step and finally elongation at $72^{\circ} \mathrm{C}$ for $5 \mathrm{~min}$. The primer sequence was obtained from gene bank (Accession no: EF092913).

Amplified products were mixed with $6 \mathrm{x}$ loading dye (MBI-Fermentas, USA) and separated by Agarose gel electrophoresis (1\% Agarose in $1 \mathrm{X}$ TBE at $70 \mathrm{~V}$, $400 \mathrm{mAmp}$ for $1 \mathrm{~h}$ ) and stained with ethidium bromide. DNA fragments were observed by UV transilluminator and photographed.

All photographed gels were scanned using gel analysis software Gene Tool (syngene, UK). All gels were compared to standard markers.

Water quality determination: Water quality parameters at both sampling sites were determined at monthly intervals for a total period of 24 months. Readings for water temperature and dissolved oxygen at $1 \mathrm{~m}$ intervals were collected in situ by using a hand-held YSI meter (YSI Incorporated, USA) for up to $20 \mathrm{~m}$ deep. The clarity of water was determined using a Secchi disk (Almazan and Boyd, 1978) while the rates of water flow were measured using a current water meter (Global Water, California) at several sampling points.

Data analysis: The mean prevalences of $S$. agalactiae from both lakes were compared using the analysis of variance with LSD All-Pairwise Comparison Test (Statistix 9, USA). Pearson's correlation (Statistix 9, USA) was selected to determine the correlation between the water temperature, dissolved oxygen, rate of water flow, water clarity and the prevalence of S. agalactiae. All data were considered significant at $\mathrm{p}<0.05$.

\section{RESULTS AND DISCUSSION}

Steptococcus agalactiae isolation pattern: Streptococcus agalactiae were successfully isolated from tilapias sampled at both lakes. The bacteria that were identified as Streptococcus agalactiae corresponded to Group B streptococcus.

The mean number of tilapia that were cultured positive to $S$. agalactie was significantly $(\mathrm{p}<0.05)$ lower in Kenyir lake (6.96\%) compared to Pedu lake (18.02\%). Results in Kenyir lake revealed that the lowest percentage was $2 \%$ in October 2007 and January 2008 while the highest was recorded with $40 \%$ in October 2008 . There was no significant different ( $\mathrm{p}>0.05)$ on the mean number of tilapias that were cultured positive to $S$. agalactiae in both years of study, although $2007(8.13 \%)$ was higher compared to $2008(5.8 \%)$. However, $95.7 \%$ of positive isolation in Kenyir lake in 2007 was obtained 

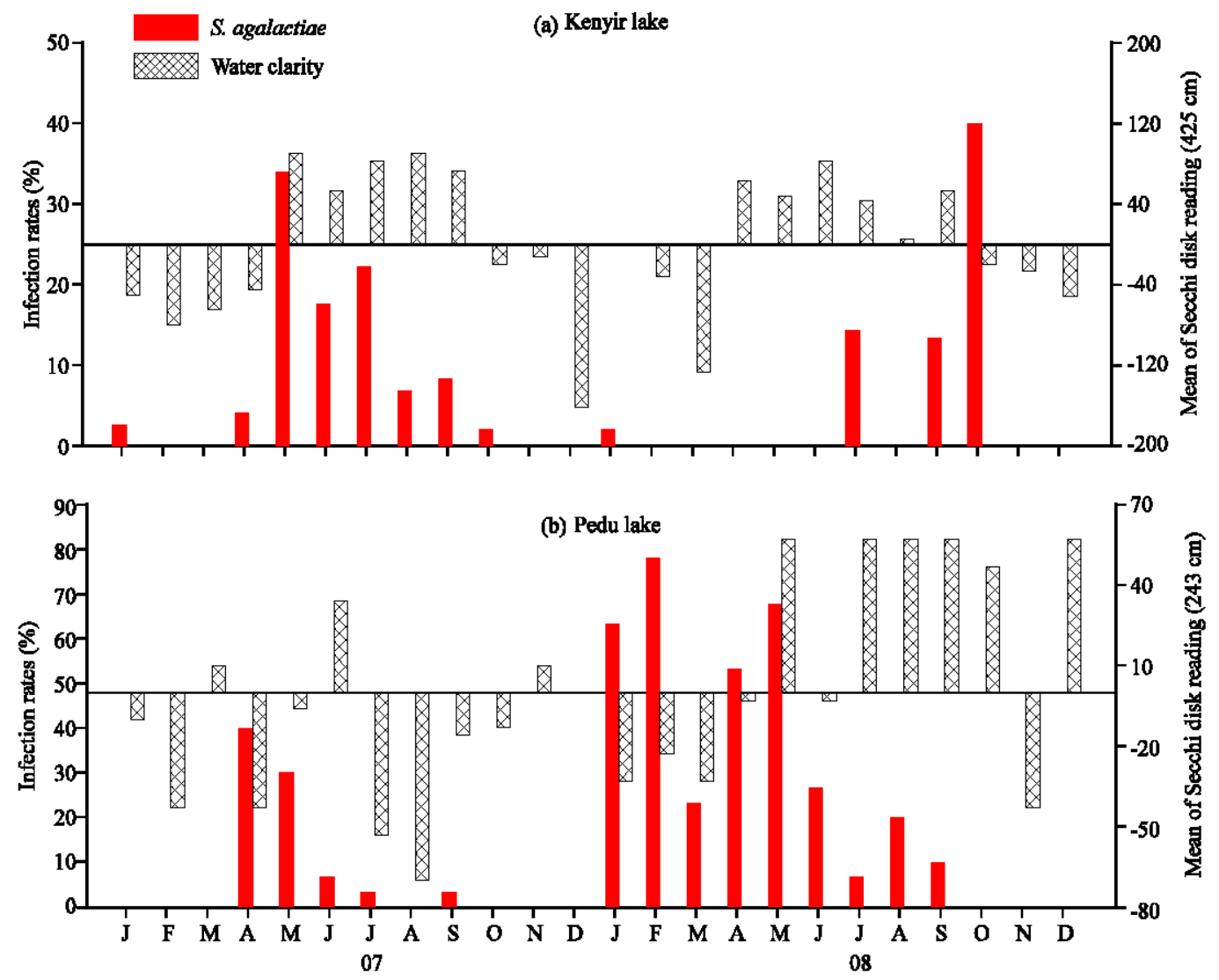

Fig. 1: Successful isolation of Streptococcus agalactiae from tilapia. Higher most rates of isolation were recorded during the 2 nd to the $3 r$ quarter of both years (Apr-Sept) which were the hot and dry months. (a) Kenyir lake showed a significant positive correlation between the water clarity $(\mathrm{r}=0.4024, \mathrm{p}<0.05)$ and the prevalence of $S$. agalactiae while most of the tilapias that cultured positive to $S$. agalactiae in Kenyir lake were obtained when the Secchi disk readings were recorded $>425 \mathrm{~cm}$. (B) no significant correlation was recorded between the water clarity and the prevalence of $S$. agalactiae in Pedu lake

during the 2 nd and the $3 r$ quarters of the year (April to September) while $95.2 \%$ of positive isolation in 2008 was in July to October (Fig. 1).

Results in Pedu lake revealed that the lowest percentage was $3.3 \%$ in July and September 2007 while the highest was $78 \%$ in February 2008. The positive isolation in $2007(6.9 \%)$ was significantly $(\mathrm{p}<0.05)$ higher compared to 2008 (29.1\%). Approximately $96 \%$ of positive isolation in 2007 was obtained between April and July while $97.2 \%$ in 2008 was between January and August.

Water temperature profiling: The mean of water temperature between 0 and $20 \mathrm{~m}$ deep at Pedu lake $\left(28.67^{\circ} \mathrm{C}\right)$ was significantly $(\mathrm{p}<0.05)$ higher compared to Kenyir lake $\left(28.17^{\circ} \mathrm{C}\right)$. There was however, no significant different $(p>0.05)$ in the mean water temperature for up to $4 \mathrm{~m}$ deep between Pedu lake $\left(29.44^{\circ} \mathrm{C}\right)$ and Kenyir lake $\left(29.22^{\circ} \mathrm{C}\right)$. Study in Kenyir lake revealed a significant different $(\mathrm{p}<0.05)$ in the mean water temperature between $2007\left(28.41^{\circ} \mathrm{C}\right)$ and $2008\left(27.93^{\circ} \mathrm{C}\right)$. The highest mean water temperature $\left(31.11^{\circ} \mathrm{C}\right.$ ) in Kenyir lake was recorded in August 2007 at $0 \mathrm{~m}$ and the lowest $\left(24.78^{\circ} \mathrm{C}\right)$ was in March 2008 at $20 \mathrm{~m}$ depth.

The water stratification and thermocline were observed to occur at $<14 \mathrm{~m}$ deep. Nevertheless, the high water temperature column $\left(\geq 29^{\circ} \mathrm{C}\right)$ was mostly noted between 0 and $8 \mathrm{~m}$ deep between March and November 2007 and April and November 2008 (Fig. 2). Study in Pedu lake showed no significant different $(\mathrm{p}<0.05)$ in the mean water temperature between $2007\left(28.76^{\circ} \mathrm{C}\right)$ and 2008 $\left(28.60^{\circ} \mathrm{C}\right)$. The highest mean watertemperature of $31.58^{\circ} \mathrm{C}$ was recorded in May 2007 at 2 and $3 \mathrm{~m}$ depth while the lowest was of $25.95^{\circ} \mathrm{C}$ was recorded in April 2007 at $20 \mathrm{~m}$ depth. Contrary to Kenyir lake, the water stratification and thermocline in Pedu lake was not clearly observed. Slight stratification and thermocline were observed in January, February, October,November and December 2007 and 

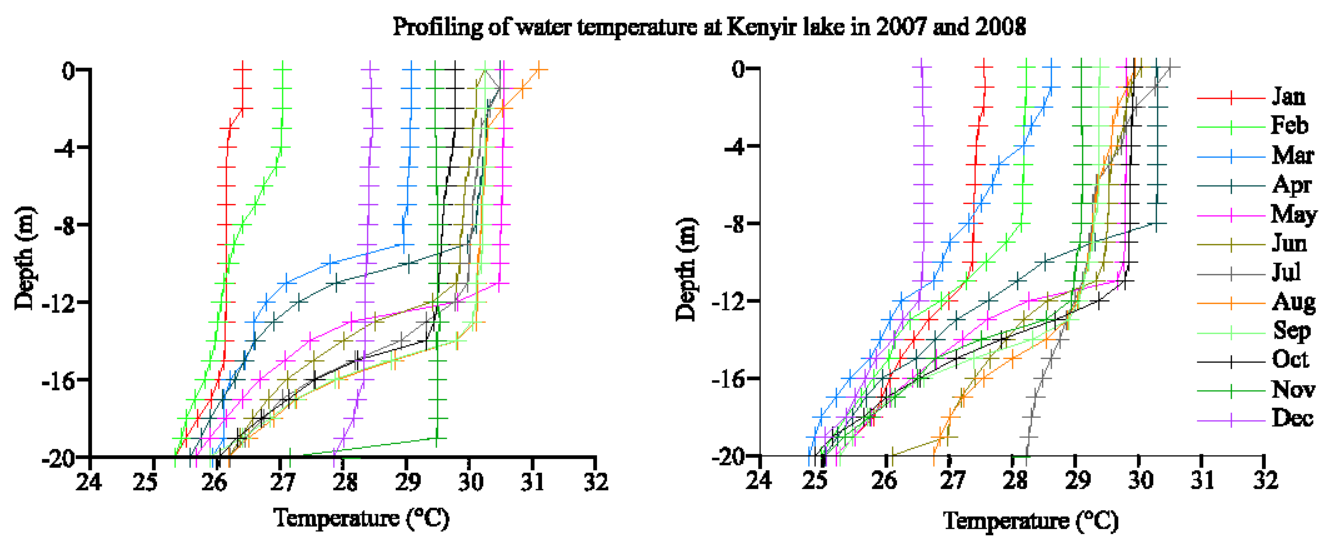

Profiling of water temperature at Pedu lake in 2007 and 2008
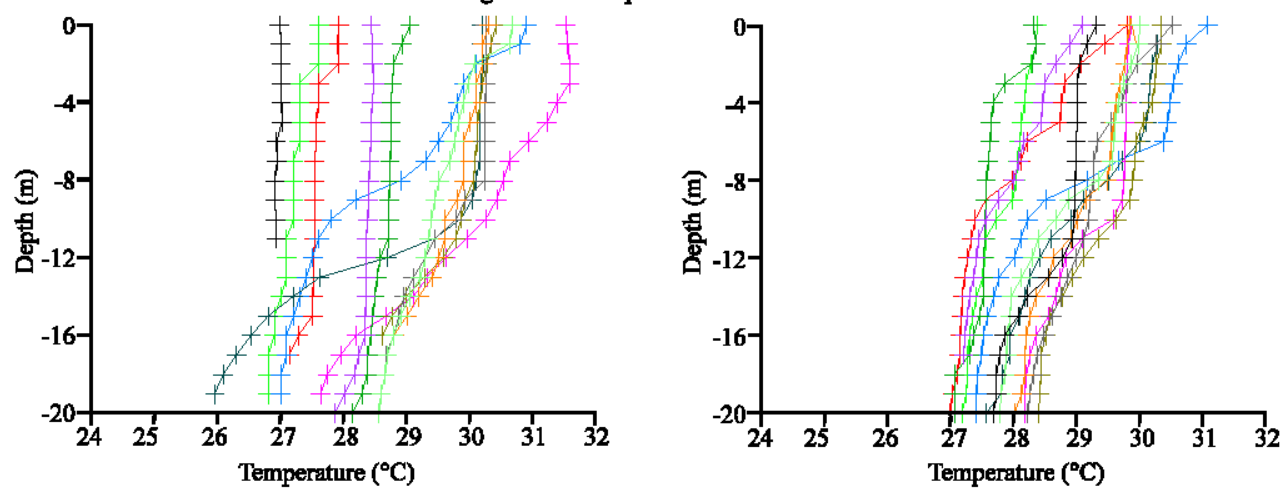

Fig. 2: The water thermocline patterns in Kenyir lake were observed at $<12 \mathrm{~m}$ deep of the water in both years but this phenomenon did not benefit tilapias that were kept at $4 \mathrm{~m}$ deep. Water thermocline was not clearly observed in Pedu lake. The high water temperature columns $\left(\geq 29^{\circ} \mathrm{C}\right)$ remained until $8 \mathrm{~m}$ deep in both lakes for both years

throughout 2008. However, the high water temperature of $\geq 29^{\circ} \mathrm{C}$ for up to $8 \mathrm{~m}$ deep was recorded between April and September 2007 and between March and September 2008.

Dissolved oxygen profiling: There was no significant different $(p>0.05)$ between the mean reading of Dissolved Oxygen (DO) between 0 and $20 \mathrm{~m}$ deep for Kenyir (5.53 $\mathrm{mg} \mathrm{L}^{-1}$ ) and Pedu (5.40 $\mathrm{mg} \mathrm{L}^{-1}$ ) lakes throughout the study period. Similarly, there was insignificant different $(\mathrm{p}>0.05)$ in the mean DO reading for up to $4 \mathrm{~m}$ deep in Kenyir (7.58 $\mathrm{mg} \mathrm{L}^{-1}$ ) and Pedu (7.50 $\mathrm{mg} \mathrm{L}^{-1}$ ) lakes. Nevertheless, the highest DO reading for Kenyir lake was $9.95 \mathrm{mg} \mathrm{L}^{-1}$ in April 2007 at $0 \mathrm{~m}$ while the lowest was $0 \mathrm{mg} \mathrm{L}^{-1}$ in October 2007 at 16-20 $\mathrm{m}$ deep.

As observed for water stratification and thermocline, the sudden drop in water DO was observed at 8-12 $\mathrm{m}$ deep when the DO readings were $>5 \mathrm{mg} \mathrm{L}^{-1}$ up till $12 \mathrm{~m}$ deep (Fig. 3). In Pedu lake, the highest DO reading was $9.3 \mathrm{mg} \mathrm{L}^{-1}$ in February 2007 at 10 and $11 \mathrm{~m}$ while the lowest was $0.13 \mathrm{mg} \mathrm{L}^{-1}$ in September 2007 at o m deep. Similarly, the high $O D$ reading of $>5 \mathrm{mg} \mathrm{L}^{-1}$ was recorded up to $8 \mathrm{~m}$ deep.
The rates of water flow and water clarity: The mean rates of water flow at Kenyir and Pedu lakes were $0.005 \pm 0.008$ $\mathrm{cm} \mathrm{sec}^{-1}$ and $0.010 \pm 0.016 \mathrm{~cm} \mathrm{sec}^{-1}$, respectively. The mean water clarity reading in Kenyir lake was $425 \mathrm{~cm}$ with lowest at $263 \mathrm{~cm}$ in December 2007 and highest at $515 \mathrm{~cm}$ in May 2007. For Pedu lake, the mean water clarity was 243 $\mathrm{cm}$ with lowest water clarity at $173 \mathrm{~cm}$ in July 2008 and highest at $300 \mathrm{~cm}$ in May, July, August, September and December of 2008.

Analysis of water quality parameters in Kenyir lake revealed a significant positive correlation between water clarity $(\mathrm{r}=0.4024, \mathrm{p}<0.05)$ and the prevalence of $S$. agalactiae. Isolation rate of $76.5 \%$ was recorded when the water clarity was $>425 \mathrm{~cm}$ which was between May and September 2007 and between April and September 2008 (Fig. 1). There was also significant positive correlation between water temperature and water flow $(\mathrm{r}=0.8584, \mathrm{p}<0.05)$ and water clarity $(\mathrm{r}=0.7510, \mathrm{p}<0.05)$, respectively. Analysis of water quality parameters in Pedu lake, $\mathrm{p}<0.05$ ), however, revealed no significant correlation $(\mathrm{p}<0.05)$ between water quality parameters and isolation of $S$. agalactiae. Streptococcus agalactiae had been 

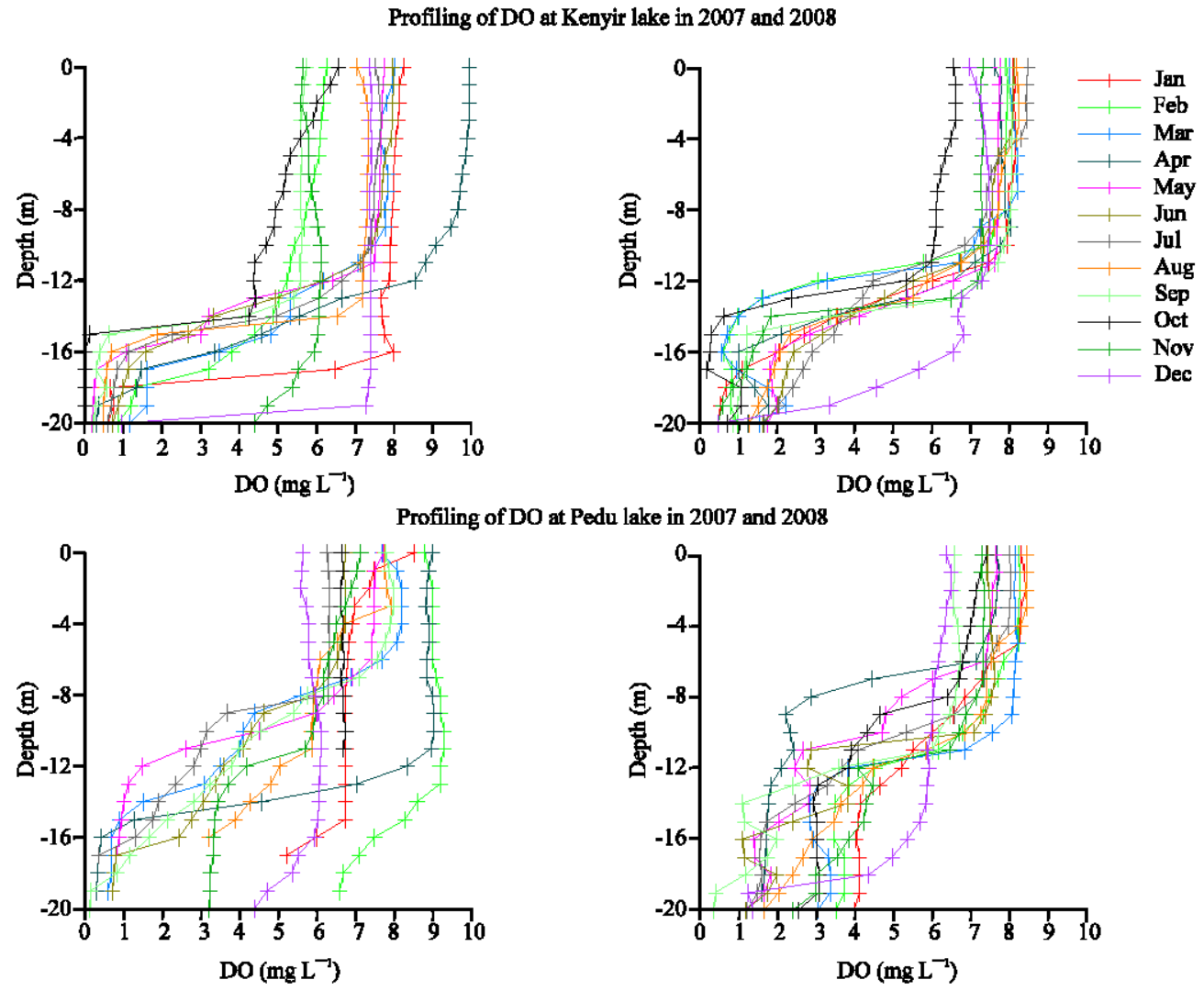

Fig. 3: The mean Dissolved Oxygen (DO) readings recorded $>5 \mathrm{mg} \mathrm{L}^{-1}$ until $8 \mathrm{~m}$ deep in both lakes. Most of the stratification and sudden drop of DO could be observed after $12 \mathrm{~m}$ deep. These high levels of DO between 0 and $8 \mathrm{~m}$ deep lake water should be beneficial to tilapias kept at $4 \mathrm{~m}$ deep under the cage culture system

successfully isolated from Kenyir and Pedu lakes during the 24 months study period. However, isolation rate of S. agalactie was significantly $(\mathrm{p}<0.05)$ lower in Kenyir (6.96\%) compared to Pedu lake (18.02\%).

Long exposures to high water temperature in Pedu lake $\left(28.67^{\circ} \mathrm{C}\right)$ cause severe stress leading to decreased immunity and enhances susceptibility to $S$. agalactiae infection. This is in agreement with study by Bunch and Bajerano (1997) when they stated that even a small difference in water temperature may have had an influence on the ability of the fish to defeat infection while Amal et al. (2010) concluded that high water temperature increases the susceptibility of tilapia to streptococcosis, particularly in floating cage systems (Mian et al., 2009). Similarly, most isolation in this study was made in the dry and hot months when water temperature was $\geq 29^{\circ} \mathrm{C}$. The high water temperature and thermocline were recorded between 0-8 $\mathrm{m}$ deep.

Since tilapias under the culture cage system were kept at maximum $4 \mathrm{~m}$ depth and tilapias were not able to escape the high water temperature column between 0 and $8 \mathrm{~m}$ depth (El-Sayed et al., 1996). Therefore, the prolonged exposure to the high water temperature resulted in the increased rate of $S$. agalactiae isolation. Slow water flow and high water clarity in reservoir play important roles in increasing the water temperature. Light energy is absorbed exponentially with depth so, most of the heat is absorbed within the upper layer of water (Boyd and Tucker, 1998). In addition, the clear water of lakes resulted in deeper light penetration causing heat retention within the water column.

The penetration of light up to $515 \mathrm{~cm}$ (Kenyir lake) and $300 \mathrm{~cm}$ (Pedu lake) deep of water surface during hot and dry season actually increased the surface water temperature and stressed to the cultured tilapias. Mixing of upper and lower water columns in Pedu lake due to the continued release of water for the paddy field irrigation and heavy rainfall destroyed the stratification and thermal change profiling of the water.

This created a condition of high water temperature up to $20 \mathrm{~m}$ deep in Pedu lake that significantly influenced the susceptibility of tilapias to $S$. agalactiae infection and resulted in more tilapias were cultured positive to $S$. agalactiae in Pedu lake. In contrast, water mixing was not 
obvious in Kenyir lake. The turbines of Kenyir lake are situated $\pm 18 \mathrm{~m}$ deep and far from the bottom of the lake $(145 \mathrm{~m})$. Thus, it reduces the possibilities to destroying water thermal change and stratification that affect the susceptibility (Zulkafli and Ahmad, 2000).

Water thermoclines in both lakes were observed at $<14 \mathrm{~m}$ deep. The thermal regime in lakes depends mostly on geographical location, climatic conditions and hydrological character (Skowron, 2010). The results showed that the occurrence of water thermocline, especially in Kenyir lake was caused by the heat accumulation between $\mathrm{o}$ and $14 \mathrm{~m}$ deep and the accumulation of heat was due to deep light penetration under the water surface and the low recirculation of water.

In this study, the monthly dissolved oxygen concentrations were recorded $>5 \mathrm{mg} \mathrm{L}^{-1}$, especially during the hot and dry months. And the high DO concentrations were only observed from $0-12 \mathrm{~m}$ deep. The high temperatures in fish ponds are a problem since, there is less DO in the water, subjecting the fish to stress (Bunch and Bajerano, 1997). However, in the present study, the DO was not as low as expected probably due to the high water clarity that enhanced deeper light penetration and photosynthesis process.

\section{ACKNOWLEDGEMENTS}

The researchers thanks all staffs of Bacteriology and Water Quality Units, National Fish Health Research Centre (NAFISH) Penang, Fisheries Department of Terengganu, Water Quality Unit from Freshwater Fisheries Research Center (FFRC) Jelebu and Muda Agricultural Development Authority (MADA).

\section{REFERENCES}

Almazan, G. and C.E. Boyd, 1978. An evaluation of secchi disk visibility for estimating plankton densities in fish ponds. Hydrobiologia, 65: 601-608.

Amal, A.M.N., M. Zamri-Saad, A. Siti-Zahrah, R. Zulkafli, S. Misri, M. Nur-Nazifah and H. Shahidan, 2010. Prevalence of Streptococcus agalactiae in tilapia in flowing water ponds rivers and reservoirs. Online J. Vet. Res., 11: 153-162.

Bowser, P.R., G.A. Wooster, R.G. Getchell and M.B. Timmons, 1998. S. iniae infection of tilapia Orechromis niloticus in a recirculation production facility. J. World Aquacult. Soc., 29: 335-339.

Boyd, C.E. and C.S. Tucker, 1998. Pond Aquaculture Water Quality Management. 1st Edn., Kluwer Academic Publisher, London.
Bunch, E.C. and Y. Bajerano, 1997. The effect of environmental factors on the susceptibility of hybrid tilapia Oreochromis niloticus x Oreochromis aureus to streptococcosis. Isr. J. Aquacult. Bamidgeh, 49: 67-76.

Chang, P.H. and J.A. Plumb, 1996. Histopathology of experimental Streptococcus sp. infection in tilapia Oreochromis niloticus (L.) and chanel catfish Ictalarus ounctatus (Rafinesque). J. Fish Dis., 19: 235-241.

El-Sayed, A.F.M., A. El-Ghobashy and M.M. Al-Amoudi, 1996. Effects of pond depth and water temperature on the growth mortality and body composition of Nile tilapia Oreochromis niloticus (L.). Aquacult. Res., 27: 681-687.

Evans, J.J., D.J. Pasnik, P.H. Klesius and C.A. Shoemaker, 2006. Identification and epidemiology of Streptococcus iniae and Streptococcus agalactiae in tilapia Oreochromis spp. Proceedings of the International Symposium on Tilapia in Aquaculture, Sept. 6, American Tilapia Association, Charles Town, WV, USA., pp: 25-42.

Evans, J.J., P.H. Klesius, P,M. Gilbert, C.A. Shoemaker and M.A. Al-Sarawi et al., 2002. Characterization of $\beta$ hemolytic group B Streptococcus agalactiae in cultured seabream Sparus auratus and and mullet Liza klunzingeri in Kuwait. J. Fish Dis., 25: 505-513.

Holt, J.G., N.R. Krieg, P.A. Sheath, J.T. Staley and S.T. William, 1994. Bergey's Manual of Determination Bacteriology. 9th Edn., William and Wilkins Co. Waverly Press, Philadelphia, PA, USA., pp: 532-558.

Mian, G.F., D.T. Godoy, C.A.G. Lea, Y.T. Yuhara, G.M. Costa and H.C.P. Figueiredo, 2009. Aspects of the natural history and virulence of $S$. agalactiae infection in Nile tilapia. Vet. Microbiol., 136: 180-183.

Najiah, M., S.W. Lee, S.W.M. Nadirah, H. Ruhil and K.L. Lee et al., 2009. Streptococcosis in red hybrid tilapia (Oreochromis niloticus) commercial farms in Malaysia. Aquacult. Res., 40: 630-632.

Plumb, J.A., J.H. Schachte, J.L. Gaines, W. Peltier and B. Carrol, 1974. Streptococcus sp. from marine fishes along the Alabama and northwest Florida coast of the Gulf of Mexico. Trans. Am. Fish. Soc., 103: 358-361.

Robinson, J.A. and F.P. Meyer, 1966. Streptococcal fish pathogen. J. Bacteriol., 92: 512-512.

Shoemaker C.A., J.J. Evans and P.H. Klesius, 2000. Density and doses: Factors affecting mortality of Streptococcus iniae infected tilapia (Oreochromis niloticus). Aquaculture, 188: 229-235.

Shoemaker, C. and P. Klesius, 1997. Streptococcal Disease Problems and Control: Review. Vol. 2, Tilapia Aquaculture, Ithaca, New York, USA., pp: 671-80. 
Skowron, R., 2010. The thermocline layer in the thermal water structure of selected Polish lakes. Limnol. Rev., 7: 161-169.

Suanyuk, N., F. Kong, D. Ko, L. Gwendolyn, G.L. Gilbert and K. Supamattaya, 2008. Occurrence of rare genotypes of Streptococcus agalactiae in cultured red tilapia Oreochromis sp. and Nile tilapia $O$. niloticus in Thailand-Relationship to human isolates. Aquaculture, 284: 35-40.
Yanong, R.P.E. and R. Francis-Floyd, 2002. Streptococcal infections of fish. Report from University of Florida. Series from the Department of Fisheries and Aquatic Sciences, Florida Cooperative Extension Service, Institute of Food and Agricultural Sciences, University of Florida.

Zulkafli, A.R. and A.O. Ahmad, 2000. Fish Fauna in Kenyir Lake. Percetakan Nasional Malaysia Berhad, Malaysia, pp: 1-50. 